\title{
Representasi Perempuan Tangguh dalam Video Game Dreadout: Sebuah Kajian Adaptasi
}

\section{(Strong Women's Representation in Video Game Dreadout: An Adaptation Study)}

\author{
Nirmala Khairunnisa Budi \\ Fakultas Ilmu Pengetahuan Budaya, Universitas Indonesia \\ Jalan Prof. Dr. Selo Soemardjan Kampus, Depok 16424 \\ Tel.: +62(21)7863528 \\ Surel: nirmala.khairunnisa@ui.ac.id
}

\begin{abstract}
Abstrak
Penelitian ini bertujuan untuk mengungkap representasi perempuan tangguh dalam video game Dreadout yang diadaptasi dari buku komik berjudul Dreadout. Perempuan selalu digambarkan memiliki kepribadian yang lemah, irasional, dan pasif, sedangkan laki-laki selalu digambarkan memiliki kepribadian yang kuat, rasional, dan aktif. Stereotip mengenai laki-laki dan perempuan dapat memengaruhi posisi seseorang dalam kehidupan sosialnya. Stereotip gender menjadi tema utama yang diangkat oleh Digital Happiness yang merilis dua media dengan ideologi yang berbeda, yaitu buku komik Dreadout dan video game Dreadout. Berbeda dengan buku komiknya yang menceritakan pria sebagai karakter utama yang mengesankan, video game Dreadout menggambarkan wanita sebagai karakter utama yang mengesankan. Untuk mencapai tujuan penelitian ini, digunakan metode kualitatif dengan pendekatan analisis adaptasi. Untuk menganalisis data, teori gender Judith Butler dan skema aktan A. J. Greimas juga digunakan. Hasil penelitian ini menunjukkan bahwa penggambaran karakter Linda dalam video game Dreadout telah berubah dan mematahkan ideologi yang telah disampaikan di media sebelumnya. Dengan kata lain, video game Dreadout tidak memperkuat stereotip gender yang biasa ditemukan di media lain, tetapi menawarkan perspektif baru tentang perempuan dengan ciri-ciri maskulin. Oleh karena itu, dapat disimpulkan bahwa representasi perempuan dalam adaptasi video game Dreadout berbeda dengan buku komik.
\end{abstract}

Kata kunci: kajian adaptasi, perempuan tangguh, stereotip gender

\begin{abstract}
This study aims to reveal the representation of strong women in video game Dreadout adapted from a comic book entitled Dreadout. Unlike the comic book entitle Dreadout narrating men as impressive main characters, video game Dreadout portrays women as impressive main characters. To pursue the aim of this study, qualitative method was used together with adaptation analysis approach. To analyse data, Judith Butler's gender theory and A. J. Greimas' schema of actant 206
\end{abstract}


were also used. The results of this study showed that the portrayal of Linda's character in video game Dreadout has changed and broke the ideology that has been conveyed in the previous media. In other words, video game Dreadout does not reinforce gender stereotypes commonly found in other media, but offers a new perspective of women with masculine traits. Hence, it can be concluded that the representation of women in Dreadout's video game adaptation is different from the comic book.

Keywords: adaptation studies, gender stereotypes, strong women

\section{PENDAHULUAN}

Perempuan selalu digambarkan memiliki kepribadian yang lemah, irasional, dan emosional, sedangkan laki-laki selalu digambarkan memiliki kepribadian yang kuat, rasional, dan aktif (Fakih 2013). Perbedaan kepribadian yang berdasarkan jenis kelamin dapat memunculkan stereotip gender. Stereotip gender merupakan konstruksi yang telah mengakar dalam kehidupan sosial masyarakat (Fakih 2013). Stereotip gender juga memengaruhi kedudukan seseorang dalam menjalani hidupnya, seperti laki-laki diperbolehkan untuk berkegiatan di luar rumah, sedangkan perempuan tidak diperbolehkan untuk berkegiatan di luar rumah. Perempuan dianggap memiliki tugas yang harus dilakukan di dalam rumah secara alami, seperti mengurus rumah. Tugas perempuan ini telah melekat dengan stereotip gender yang telah mengakar dalam kehidupan (Chodorow 1983).

Stereotip mengenai laki-laki dan perempuan dapat ditemui dalam berbagai macam media hiburan, seperti film dan video game. Video game dapat dikategorikan dalam dua jenis, yaitu video game untuk anak laki-laki dan video game untuk anak perempuan. Perbedaan jenis video game berdasarkan dengan tema permainan yang diangkat dalam game tersebut, seperti game perang untuk anak laki-laki dan game memasak untuk anak perempuan (Sunden \& Sveningsson 2012). Game anak perempuan lebih dikenal sebagai game merah muda yang diciptakan berdasarkan dengan konsep stereotip gender (Sunden \& Sveningsson 2012). Game merah muda menampilkan permainan yang berkaitan dengan stereotip perempuan, seperti memasak, menjahit, dan membersihkan rumah. Game merah muda juga dimainkan oleh anak-anak perempuan. Hal ini dapat menunjukkan bahwa konsep stereotip gender telah disosialisasikan kepada anak-anak melalui penggambaran tokoh perempuan di game tersebut. Namun, seiring perkembangan zaman, perempuan mulai digambarkan sebagai sosok yang berbeda dengan stereotip gender, terutama melalui video game. Video game tidak menggambarkan perempuan sebagai sosok yang bertanggung jawab untuk mengurus kebersihan rumah, tetapi digambarkan sebagai sosok yang memiliki kesamaan peran dengan laki-laki. Perempuan dapat dihadirkan sebagai sosok yang penting dalam video game, seperti game perang. Penggambaran perempuan sebagai tokoh utama yang tangguh dapat ditemui dalam beberapa game seperti Tomb Raider, Dota, Resident Evil, Battlefield, dan Dreadout.

Dreadout menghadirkan perempuan sebagai tokoh utama dalam video game genre horor kesintasan. Video game ini dikembangkan oleh pengembang yang berasal dari Indonesia, yaitu Digital Happiness. Digital Happiness telah berdiri sejak tahun 2012, tetapi baru berdiri secara resmi pada tahun 2013. Pada tahun 2014, Digital Happiness merilis video game Dreadout: Act 1 dan Dreadout: Act 2 yang diadaptasi dari buku komik Dreadout (2013). Buku komik Dreadout juga dirilis oleh Digital happiness. Buku komik dan video game Dreadout memiliki kesamaan genre dan tema, tetapi video game menampilkan cerita dan tokoh yang berbeda dengan buku komik. Buku komik menggambarkan tokoh Bayu sebagai tokoh utama laki-laki yang memiliki peran penting 
dan dibutuhkan oleh tokoh-tokoh lainnya. Tokoh Bayu digambarkan sebagai sosok yang tangguh dan dominan dalam buku komik. Penggambaran tokoh Bayu dapat menunjukkan citraan lakilaki yang sesuai dengan stereotip gender. Penggambaran tokoh laki-laki sebagai tokoh dominan dan tangguh tidak dihadirkan kembali dalam video game Dreadout. Video game ini menghadirkan tokoh perempuan sebagai tokoh utama yang memiliki kesamaan kepribadian dengan tokoh Bayu dalam buku komik. Pengubahan tokoh utama laki-laki menjadi tokoh utama perempuan dapat menunjukkan bahwa Digital Happiness ingin memberikan interpretasi baru terhadap media adaptasi buku komik Dreadout.

Berdasarkan pemaparan di atas, hipotesis yang diajukan dalam penelitian ini adalah pengubahan citraan dan peranan perempuan dalam video game aksi dapat menunjukkan distorsi stereotip gender. Dalam mendukung hipotesis ini, penelitian ini mengkaji penelitian terdahulu terkait korpus penelitian dan topik penelitian. Penelitian terdahulu terkait korpus sudah beberapa kali dilakukan, seperti Putra (2018), Leondra (2018), dan Adi (2015). Penelitian pertama menyoroti poster Dreadout yang menggambarkan budaya Indonesia untuk menarik penggemar di luar negeri. Penelitian kedua menyoroti visual Linda yang dianggap sensual dalam video game Dreadout. Penelitian ketiga berfokus dengan pemasaran video game melalui internet. Ketiga penelitian ini hanya menyoroti satu media Dreadout, seperti poster dan video game.

Penelitian terdahulu terkait topik penelitian telah dilakukan oleh Fehrle (2015) dan Kaklamanidou (2013). Fehrle menyoroti kaitan antara adaptasi video game dengan moralitas pemain, sedangkan Kaklamanidou menyoroti pengubahan gender tokoh utama dalam adaptasi video game. Kedua penelitian ini memiliki kesamaan dalam mengkaji adaptasi video game, tetapi memiliki metode penelitian yang berbeda. Fehrle (2015) memaparkan bahwa video game memberikan kesempatan kepada pemain untuk menentukan narasi game. Dalam menentukan narasi game, pemain memiliki beberapa cara permainan atau ludologi melalui sifat interaktifnya. Pemain dapat memilih pilihan yang ditampilkan dalam game dan menjelajahi dunia game secara bebas. Pandangan Fehrle mengenai ludologi yang dianggap penting dalam penelitian game diabaikan oleh Kaklamanidou. Kaklamanidou (2013) menyatakan bahwa sifat interaktif antara pemain dengan dunia game memiliki keterbatasan. Pemain diperbolehkan menjelajah dan memilih pilihan yang tersedia di dalam dunia game, tetapi kebebasan ini telah dikonstruksi oleh pembuat game. Pemain hanya memiliki kebebasan berdasarkan narasi yang telah dibuat oleh pembuat game. Hal ini dapat menunjukkan bahwa aspek ludologi pemain tidak cukup berpengaruh dalam pengembangan cerita game. Berdasarkan kelima penelitian ini, belum ditemukan penelitian alih wahana yang membahas adaptasi buku komik Dreadout menjadi video game. Maka dari itu, penelitian ini membahas representasi perempuan tangguh dalam adaptasi video game Dreadout.

Dalam membahas permasalahan representasi perempuan tangguh yang digambarkan dalam video game, penelitian ini menggunakan tiga teori, yaitu skema aktan dari A. J. Greimas, kajian adaptasi dari Linda Hutcheon, dan konsep gender dari Judith Butler. Algirdas Julien Greimas (1987) mengemukakan pandangannya mengenai fungsi dan peran setiap unsur cerita yang disebut dengan aktan. Greimas menyoroti cerita sebagai sebuah struktur makna, di mana setiap kata dalam kalimat memiliki fungsi dan perannya masing-masing (Greimas 1987). Hal ini menunjukkan bahwa tokoh dalam cerita juga memiliki fungsi dan peran yang saling terikat satu sama lain. Skema aktan terbagi menjadi enam bagian, yaitu subjek (unsur yang mencari), objek (unsur yang diinginkan oleh subjek), pengirim (unsur yang mengirim subjek), penerima (tujuan subjek), penolong (pendukung subjek), dan penghambat (menghambat subjek) (Greimas 1987). 
Keenam unsur ini dapat digambarkan dalam sebuah bagan untuk mengetahui hubungan antarunsurnya.

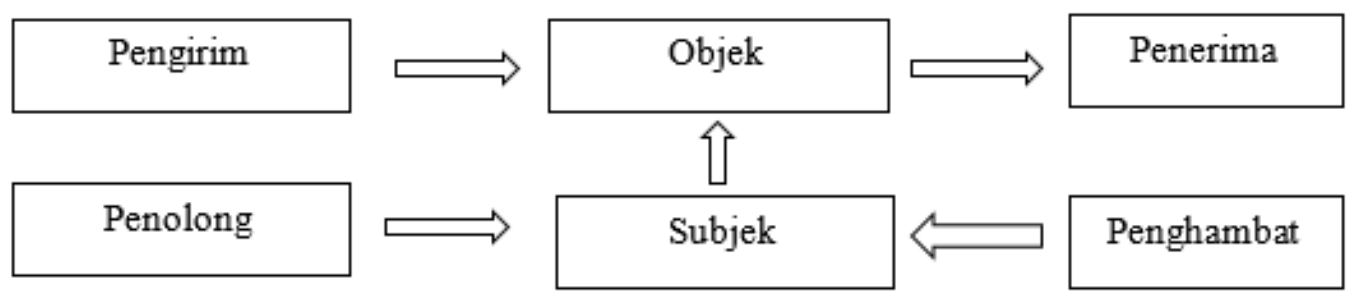

Gambar 1. Skema Aktan

Setelah membongkar fungsi dan peran antartokoh, langkah selanjutnya adalah mengaitkan temuan-temuan tersebut dengan teori adaptasi dari Linda Hutcheon. Dalam bukunya yang berjudul A Theory of Adaptation (2006), Hutcheon mengemukakan pandangannya mengenai adaptasi. Adaptasi adalah sebuah pengulangan suatu karya. Adaptasi juga dapat diartikan sebagai proses untuk mengubah dan menyesuaikan teks dengan media yang baru. Setiap teks adaptasi memiliki cerita yang berbeda (Hutcheon 2006). Pembuat adaptasi memiliki beberapa pilihan dalam menghadirkan teks adaptasi yang baru, seperti menyederhanakan, mengukuhkan, atau mengubah unsur cerita yang telah dihadirkan sebelumnya. Hutcheon menekankan bahwa teks adaptasi memiliki hubungan yang jelas dengan teks sebelumnya. Apabila teks sebelumnya telah diketahui dengan jelas, pembaca akan selalu merasakan bayangan dari teks sebelumnya. Hal ini dapat memengaruhi pembaca dalam menikmati sebuah karya adaptasi. Pembaca tidak dapat menikmati teks adaptasi sebagai sebuah karya yang baru.

Adaptasi dapat dijelaskan dalam dua hal yang saling berkaitan, yaitu proses dan produk (Hutcheon 2006). Adaptasi sebagai proses dilakukan untuk memperoleh ideologi dan pesan yang baru. Teks adaptasi dapat memiliki ideologi yang baru atau berbeda dengan teks sebelumnya. Adaptasi sebagai produk menampilkan sesuatu yang berbeda dengan teks sebelumnya. Adaptasi dapat mempertahankan unsur cerita yang dimiliki oleh teks sebelumnya atau mengubahnya menjadi sebuah karya yang baru (Hutcheon 2006). Persamaan yang terjadi antara teks adaptasi dengan teks sebelumnya lebih dikenal dengan kesetiaan. Dalam mengadaptasi sebuah teks, pembuat adaptasi memiliki berbagai macam alasan, seperti melanggengkan atau memperoleh keuntungan finansial. Pembuat adaptasi sangat tertarik dengan keuntungan yang dapat diperoleh dari suatu karya yang sukses.

Teori adaptasi yang telah dijabarkan oleh Hutcheon dapat diperdalam dengan menggunakan konsep gender dari Judith Butler. Butler (1990) mengemukakan pandangannya mengenai gender yang telah dikonstruksi oleh masyarakat. Gender memiliki pengertian yang berbeda dengan jenis kelamin. Jenis kelamin merupakan penyifatan atas dua jenis kelamin yang berdasarkan aspek biologis, seperti laki-laki adalah manusia yang memiliki jakun (Butler 1990). Jenis kelamin yang dimiliki oleh seseorang adalah sesuatu yang diberikan secara alami, sejak lahir ke dunia. Sedangkan, gender lebih mengacu terhadap sifat maskulin dan feminin berdasarkan aspek budaya (Butler 1990). Perbedaan jenis kelamin atau gender seseorang menunjukkan ketidaksinambungan antara tubuh dengan jenis kelamin yang telah dikonstruksi oleh budaya (Butler 1990). Peranan yang dimiliki oleh laki-laki dengan perempuan dalam kehidupan sosial disebabkan oleh perbedaan gender. Hal ini menunjukkan bahwa peranan laki-laki dan perempuan yang terjadi di dalam masyarakat adalah sebuah konstruksi sosial budaya. 


\section{METODE}

Penelitian ini menggunakan buku komik Dreadout dan video game Dreadout sebagai korpus penelitian. Video game Dreadout diteliti secara lebih mendalam dan dominan dalam penelitian ini. Penelitian ini adalah penelitian kualitatif yang menggunakan metode deskriptif analisis. Data yang diperoleh dari kedua korpus ini adalah narasi dan visual tokoh utama yang digambarkan pada setiap media Dreadout. Penelitian ini menggunakan teori skema akta dari A. J. Greimas untuk membongkar struktur teks, terutama peranan antartokoh. Setelah membongkar peranan antartokoh, langkah selanjutnya adalah mengaitkan temuan-temuan tersebut dengan teori adaptasi dari Linda Hutcheon. Teori adaptasi Hutcheon digunakan untuk menyoroti perbedaan peranan tokoh dalam buku komik dengan video game Dreadout. Teori adaptasi yang telah dipaparkan oleh Hutcheon akan diperdalam dengan konsep gender dari Judith Butler. Konsep gender Butler digunakan untuk membongkar konstruksi gender yang telah mengakar dalam kehidupan masyarakat.

\section{HASIL DAN PEMBAHASAN}

\section{Perbedaan Narasi dalam Buku Komik dan Video Game}

\section{Buku Komik Dreadout: Tokoh Utama Laki-Laki}

Buku komik Dreadout dirilis oleh Digital Happiness pada tahun 2013. Komik ini memiliki dua bagian cerita yang berbeda, tetapi memiliki judul dan unsur cerita yang sama. Bagian pertama menceritakan sebuah keluarga yang sedang melakukan perjalanan pindah rumah dari kota ke desa. Keluarga tersebut terdiri atas lima tokoh, yaitu Bayu (tokoh utama), Kiki, Nia, Mama, dan Papa. Selama perjalanan menuju desa tersebut, mobil yang mereka gunakan tidak bisa menyeberang jembatan. Sebuah pohon besar menghalangi jalan masuk jembatan. Mereka memutuskan untuk meninggalkan mobil dan berjalan kaki menyeberang jembatan. Mereka memasuki sebuah daerah pemukiman yang sepi. Di dalam daerah pemukiman ini, mereka terpisah satu sama lain dan bertemu hantu. Sementara itu, bagian kedua menceritakan pasukan tentara Indonesia yang dikejar oleh pasukan tentara Jepang. Sarip (tentara Indonesia) memberikan saran kepada komandannya untuk bersembunyi di sebuah gedung besar. Tentara Jepang juga mengikuti langkah tentara Indonesia untuk memasuki gedung besar tersebut. Di dalam gedung ini, kedua kelompok tentara bertemu dan diserang pasukan pocong.

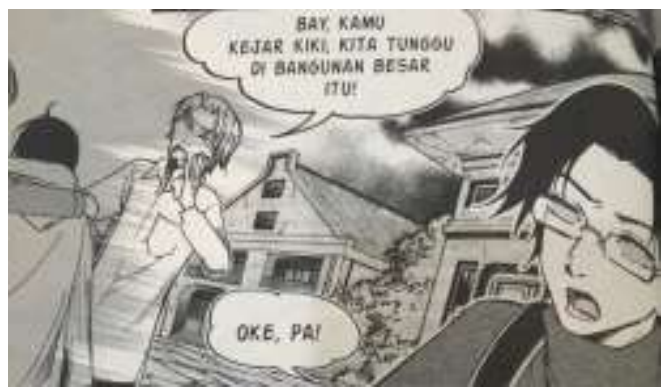

Gambar 2. Bayu mencari anggota keluarganya

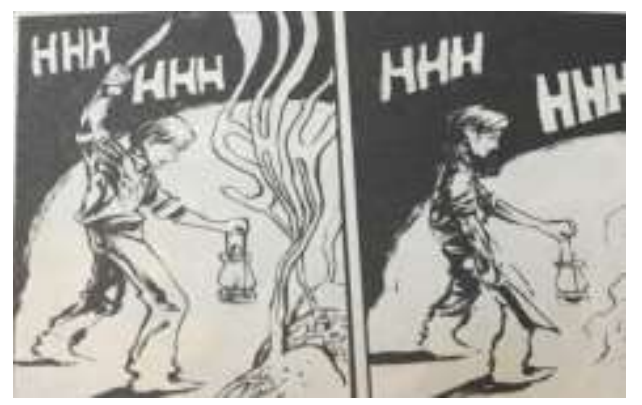

Gambar 3. Perlawanan Sarip terhadap pocong

Kedua cerita komik ini menggunakan seorang laki-laki sebagai tokoh utama yang memiliki peran sangat penting dalam menjalankan cerita. Pada cerita pertama, tokoh Bayu digambarkan sebagai satu-satunya anak laki-laki dalam keluarga tersebut. Bayu memiliki sifat maskulin yang ditunjukkan dengan keberaniannya, keaktifannya, dan melindungi seluruh anggota keluarganya, terutama tokoh perempuan. Tokoh-tokoh perempuan digambarkan sebagai seseorang yang lemah, pasif, dan sangat bergantung dengan Bayu. Sementara itu, pada bagian kedua, seluruh tokohnya adalah laki-laki. Sarip sebagai tokoh utama juga memiliki keberanian untuk 
berhadapan dengan pocong di dalam gedung tersebut. Namun, Sarip tidak menolong tokohtokoh lainnya, terutama anggota pasukan tentara Indonesia. Sarip hanya mengamati kematian tokoh-tokoh lainnya melalui jendela di lantai atas gedung tersebut. Penggambaran watak Sarip sangat berbeda dengan Bayu dalam menolong tokoh-tokoh lainnya, tetapi kedua tokoh utama ini merepresentasikan stereotip mengenai laki-laki, seperti maskulin, berani, mandiri, aktif, dan kuat.

\section{Video Game Dreadout: Tokoh Utama Perempuan}

Kedua cerita buku komik Dreadout mengalami pengubahan cerita dalam video game. Video game Dreadout menceritakan perjalanan kelima tokoh murid SMA dengan seorang guru perempuan yang akan pergi berlibur. Keenam tokoh ini adalah Linda (tokoh utama), Ira, Shelly, Doni, Yayan, dan $\mathrm{Bu}$ Siska. Perjalanan mereka terhenti karena mobil yang mereka gunakan tidak bisa menyeberang jembatan yang telah rusak. Mereka memutuskan untuk berjalan kaki dan menemukan sebuah kota yang telah lama ditinggalkan. Di dalam kota tersebut, mereka memasuki sebuah gedung sekolah tua. Ketika berada di dalamnya, mereka terpisah dan bertemu dengan berbagai macam hantu seperti tuyul, kuntilanak, babi ngepet, sundel bolong, dan pocong.

Penggambaran alur cerita video game merupakan gabungan dari kedua cerita buku komik. Video game menghadirkan kembali unsur horor yang telah digambarkan dalam buku komik, seperti memasuki daerah asing yang gelap, keheningan, dan bertemu dengan sosok menyeramkan. Unsur horor yang dihadirkan dalam video game ini dapat dimaknai sebagai pengukuhan tema yang sesuai dengan judulnya, yaitu Dreadout. Video game ini menghadirkan suasana yang menyeramkan, daerah yang dibangun dipenuhi dengan kabut dan kegelapan. Video game horor menggunakan semua trik audio-visual film horor, seperti sudut kamera, pencahayaan, keheningan mematikan, musik yang menakutkan, dan monster yang menakutkan (Perron 2009). Penggambaran unsur horor diperkuat dengan pemilihan latar tempat, seperti jembatan gantung yang rusak, kota yang tidak berpenghuni, dan gedung sekolah tua. Penggambaran daerah dan bangunan yang telah lama ditinggalkan dapat memperkuat nuansa horor dan menegangkan bagi pemain game. Latar tempat yang digunakan adalah jembatan yang rusak, kota yang telah lama ditinggalkan, dan gedung sekolah yang luas. Penggambaran latar tempat jembatan dan daerah pemukiman memiliki kesamaan dengan cerita Bayu, sedangkan gedung yang luas memiliki kesamaan dengan cerita Sarip.

Penggambaran tokoh-tokoh dalam game juga memperkuat unsur horor yang diusung oleh pembuat game, yaitu tokoh-tokoh hantu yang berada hampir di setiap sudut dunia game. Dalam cerita Bayu, tokoh-tokoh menyeramkan digambakan melalui kehadiran tokoh hantu kuntilanak dan boneka yang dirasuki oleh roh, sedangkan cerita Sarip menghadirkan hantu pocong. Ketiga jenis hantu ini dapat ditemui dalam video game, tetapi hantu-hantu yang digambarkan dalam video game memiliki jenis yang lebih banyak daripada dua cerita komik sebelumnya. Kehadiran tokohtokoh hantu juga tidak dapat diperkirakan oleh pemain. Hantu-hantu ini muncul secara tiba-tiba di setiap sudut dunia game. Pemain hanya dapat melihat potongan-potongan di sekitarnya dan dikejutkan oleh monster yang mengintai. Game horor menampilkan makhluk dan elemen mengerikan yang diintergrasikan dalam setiap bagian cerita (Perron 2009). Perron (2009) juga memaparkan bahwa game horor dapat memunculkan gagasan untuk bertahan hidup atas masalah dan kondisi yang dihadirkan dalam game. Berdasarkan ulasan ini, ketiga alur cerita Dreadout dapat digambarkan melalui tabel aktan berikut ini. 
Tabel 1. Aktan dalam Buku Komik dan Video Game

\begin{tabular}{cccc}
\hline Aktan & Komik Bagian 1 & Komik Bagian 2 & Video Game \\
\hline Subjek & Bayu & Sarip & Linda \\
\hline Objek & Keluar dari pemukiman & $\begin{array}{c}\text { Keselamatan dari } \\
\text { serangan tentara Jepang }\end{array}$ & Keluar dari kota \\
\hline Pengirim & Bayu & Sarip & Linda \\
\hline Penerima & $\begin{array}{c}\text { Seluruh anggota } \\
\text { keluarga }\end{array}$ & $\begin{array}{c}\text { Seluruh anggota tentara } \\
\text { Indonesia }\end{array}$ & $\begin{array}{c}\text { Linda dan kelima } \\
\text { tokoh lainnya }\end{array}$ \\
\hline Penolong & Bayu dan Kiki & Sarip & Linda \\
\hline Penghambat & Hantu-hantu & $\begin{array}{c}\text { Pasukan pocong dan } \\
\text { tentara Jepang }\end{array}$ & $\begin{array}{c}\text { Hantu-hantu dan Bu } \\
\text { Siska }\end{array}$ \\
\hline
\end{tabular}

Tabel 1 tersebut dibuat berdasarkan dengan skema aktan Greimas. Penggunaan tabel aktan dilakukan untuk mempermudah dalam membandingkan ketiga alur cerita Dreadout. Tabel di atas menunjukkan posisi dan tujuan yang sama dalam ketiga cerita, tetapi unsur-unsur aktan ini dilakukan oleh tokoh-tokoh yang berbeda. Dalam tabel video game, Linda digambarkan sebagai subjek yang memiliki keinginan untuk keluar dari daerah tersebut. Linda tidak hanya ingin keluar dari gedung sekolah, tetapi ia juga ingin keluar dari kota tersebut. Objek yang diinginkan oleh Linda berasal dari dirinya sendiri. Linda membuat beberapa peraturan dalam memperoleh objeknya, seperti mengelilingi gedung sekolah dan kota untuk menemukan kelima tokoh lainnya. Linda ingin mendapatkan aktan penerima, yaitu keberhasilan dirinya dan kelima tokoh lainnya untuk keluar dari kota tersebut. Tabel ini juga menggambarkan peran hantu-hantu dan Bu Siska dalam menghambat keinginan Linda, seperti hantu-hantu yang merasuki dan membunuh temantemannya. Bu Siska adalah tokoh yang memiliki peran dalam mendorong tokoh-tokoh lainnya untuk masuk ke daerah tersebut karena ia ingin mengambil anaknya dari hantu kebaya merah. Bu Siska juga menghambat keinginan Linda dengan membunuh Shelly. Dalam memperoleh objeknya, Linda memiliki aktan penolong, yaitu kemampuannya untuk membunuh hantu-hantu tersebut. Hantu-hantu ini dapat dikalahkan dengan menggunakan sinar kamera ponsel Linda. Di akhir cerita, hanya Linda dan Bu Siska yang berhasil keluar dari daerah tersebut.

Tabel aktan di atas memiliki perbedaan yang sangat mencolok, yaitu penggambaran perempuan sebagai tokoh utama dalam video game. Video game menghadirkan tokoh utama yang berbeda dengan dua tokoh utama dalam buku komik. Kedua cerita buku komik menghadirkan tokoh laki-laki sebagai tokoh utama, tetapi video game tidak menghadirkan tokoh utama laki-laki. Penggambaran tokoh utama perempuan dalam video game genre horor kesintasan sangat memengaruhi ideologi game. Video game Dreadout menciptakan sebuah dunia di mana protagonis, penolong, dan penjahat adalah perempuan. Video game ini lebih didominasi oleh perempuan yang memiliki peran sentral dalam pengembangan cerita. Tokoh laki-laki memang dihadirkan dalam video game, tetapi peran yang dimiliki oleh tokoh laki-laki ini tidak begitu memengaruhi pengembangan cerita. Tokoh laki-laki digambarkan sebagai tokoh minoritas dan pelengkap bagi pengembangan karakterisasi tokoh-tokoh sentral perempuan. Kehadiran tokoh utama perempuan dapat memunculkan berbagai macam isu, seperti mematahkan stereotip gender yang telah dikonstruksi oleh masyarakat.

\section{Representasi Perempuan Tangguh dalam Video Game}

Pemaparan narasi buku komik dan video game Dreadout dalam dua subpembahasan di atas menunjukkan proses adaptasi antara teks adaptasi dengan teks pertama yang tidak seutuhnya sama. Teks pertama adalah buku komik Dreadout, sedangkan teks adaptasi adalah video game Dreadout. Teks adaptasi atau video game menggambarkan kembali unsur-unsur yang diangkat 
dalam cerita komik Dreadout. Penggambaran tersebut dapat menunjukkan keterkaitan cerita antara teks pertama dengan teks adaptasi. Kehadiran unsur-unsur pembangun teks pertama dalam teks adaptasi dapat menjadi tanda adanya proses adaptasi suatu karya. Penggambaran ini senada dengan pemikiran Hutcheon. Hutcheon (2006) memaparkan bahwa adaptasi dapat dilakukan dengan menghadirkan kembali unsur-unsur teks pertama dalam teks adaptasi. Pengulangan unsur-unsur cerita dapat disesuaikan dengan elemen-elemen pembentuk media pada teks adaptasi. Hal ini menunjukkan bahwa pengubahan unsur-unsur teks pertama dalam teks adaptasi disebabkan oleh perbedaan media teks yang berbeda. Dalam teks pertama, cerita yang diangkat oleh penulis disampaikan melalui gambar dan narasi yang dikelompokkan dalam beberapa panel. Gambar dan narasi cerita menjadi fokus utama dalam buku komik. Namun, gambar dan narasi tidak mendapatkan fokus yang dominan dalam video game. Video game menyampaikan ceritanya dalam beberapa unsur pembangun, seperti gambar bergerak, narasi, dan suara. Kondisi ini dapat menunjukkan bahwa pengadaptasian sangat terpengaruh oleh unsurunsur pembentuk media adaptasi.

Pengadaptasian yang berbeda dengan teks pertama dapat memunculkan makna baru, terutama bagi penonton. Proses adaptasi dapat berperan sebagai proses dan produk (Hutcheon 2006). Adaptasi sebagai proses dilakukan untuk mendapatkan sebuah ideologi yang baru, sedangkan adaptasi sebagai produk dilakukan untuk memberikan perbedaan dengan teks sebelumnya. Hal ini menunjukkan bahwa pengadaptasian video game Dreadout sejalan dengan kajian adaptasi yang dikemukakan oleh Hutcheon di mana video game ini dapat berperan sebagai proses dan produk dari kajian adaptasi. Video game ini menampilkan unsur cerita yang berbeda dan dapat menciptakan ideologi yang berbeda dengan buku komik

Video game Dreadout tidak mengubah keseluruhan unsur cerita yang telah digambarkan dalam buku komik, tetapi pengubahan gender tokoh utama sangat memengaruhi ideologi cerita yang diangkat dalam teks adaptasi. Dalam kedua cerita buku komik, tokoh utama adalah seorang lakilaki yang memiliki watak tangguh dan mandiri, sedangkan tokoh-tokoh perempuan dalam cerita Bayu digambarkan memiliki watak yang pasif dan sangat bergantung pada Bayu. Tokoh-tokoh perempuan hanya digambarkan dalam bagian cerita Bayu. Penggambaran watak antara tokoh laki-laki dengan tokoh perempuan dalam cerita Bayu merepresentasikan stereotip gender. Penggambaran stereotip gender disebabkan oleh penempatan seseorang berdasarkan jenis kelaminnya. Perempuan memiliki kepribadian yang dinilai lebih cocok untuk tinggal di dalam ruang domestik, sedangkan laki-laki memiliki watak yang lebih cocok untuk berada di ruang publik (Chodorow 1983). Penggambaran seseorang berdasarkan penempatan ruang sangat memengaruhi pembentukan wataknya. Hal ini digambarkan dalam peran Bayu yang selalu berada di luar gedung, sedangkan tokoh perempuan digambarkan menunggu di dalam gedung. Penggambaran ini juga dapat mengukuhkan stereotip gender antara laki-laki dan perempuan.

Penggambaran tokoh laki-laki yang lebih dominan dalam buku komik ditampilkan berbeda dalam video game Dreadout. Video game tidak menggambarkan sebuah dunia sentral laki-laki, tetapi menampilkan sebuah dunia yang berbeda. Video game ini menampilkan tokoh utama seorang siswi perempuan SMA. Penggambaran seorang gadis remaja yang masih bersekolah dapat menunjukkan usia tokoh yang belum dewasa. Usia remaja sering dianggap tidak dapat membuat keputusan yang tepat dan matang, tetapi anggapan ketidakmatangan usia dipatahkan dalam penggambaran tokoh Linda. Tokoh Linda dapat merepresentasikan perkembangan watak dan pembuatan keputusan yang berbeda dengan stereotip. Penggambaran ini dapat ditunjukkan dalam kedua gambar berikut ini. 


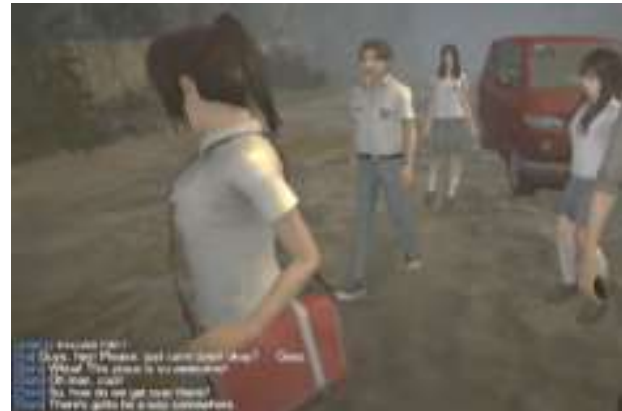

Gambar 4. Menemukan jalan rahasia

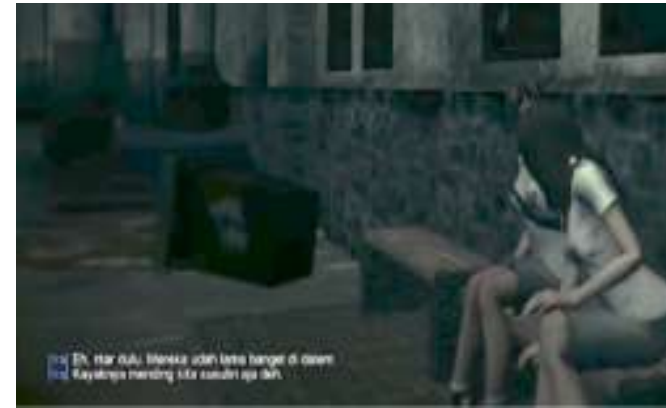

Gambar 5. Linda memasuki gedung sekolah

Gambar 4 merupakan pembukaan video game Dreadout. Video game ini dibuka dengan gambaran keenam tokoh yang berdiri di depan mobil. Keenam tokoh ini tidak dapat melanjutkan perjalanan mereka karena jembatan yang harus dilewati telah rusak. Keenam tokoh berkeliling di sekitar mobil untuk menemukan petunjuk atas permasalahan ini. Dalam gambar 4, Doni menemukan sebuah jalan rahasia untuk menyeberangi jembatan tersebut. Jalan rahasia ini tertutup oleh semak belukar dan dipenuhi alang-alang. Setelah melewati jalan rahasia ini, mereka memasuki sebuah kota yang tidak berpenghuni. Di dalam kota tersebut, mereka menemukan sebuah gedung sekolah tua yang besar. Doni memasuki gedung terlebih dahulu karena ia merasa penasaran dengan kondisi gedung. Penggambaran gedung sekolah ditampilkan dalam gambar 5 . Dalam gambar 5, Linda dan Ira belum memasuki gedung tersebut, karena mereka sedang asyik bermain. Namun, setelah malam tiba, teman-teman mereka yang telah memasuki gedung masih belum keluar.

Dalam gambar 4 dan 5, Linda tidak digambarkan sebagai tokoh yang dominan dalam memimpin kelima tokoh lainnya. Namun, video game ini dibuka dengan kamera yang menyoroti Linda. Sorotan kamera ini dapat menunjukkan peran Linda yang penting dalam game. Linda digambarkan memakai seragam sekolah putih abu-abu. Linda dapat berganti pakaian dengan pakaian yang lebih santai, yaitu atasan putih tanpa lengan, celana jeans, dan sandal jepit. Dua pilihan pakaian Linda dapat menunjukkan identitas Linda sebagai murid SMA yang santai dan siaga. Selain itu, penemuan jalan rahasia dan memasuki gedung sekolah yang dilakukan oleh Doni dapat menunjukkan tokoh laki-laki memulai permasalahan. Doni menuntun kelima tokoh lainnya untuk memasuki daerah dan gedung yang membahayakan kehidupan mereka. Linda digambarkan sebagai tokoh yang terakhir memasuki daerah dan gedung tersebut, karena khawatir dengan tokoh-tokoh lain yang belum kembali.

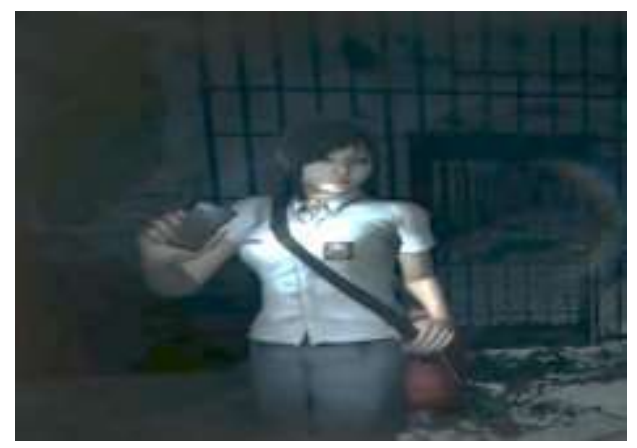

Gambar 7. Linda mencari teman-temannya

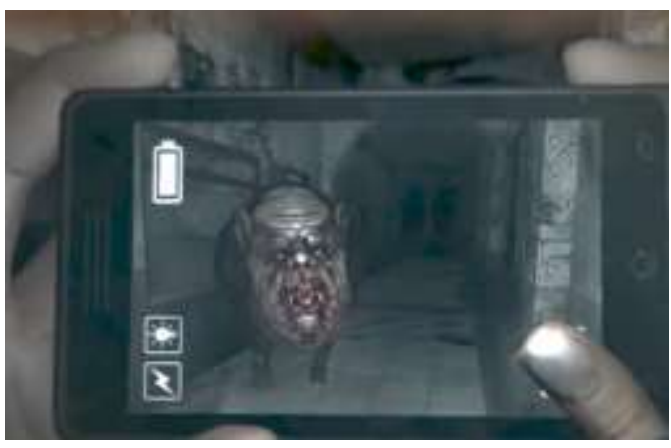

Gambar 8. Linda menghadapi babi ngepet

Gambar 7 menunjukkan Linda yang terpisah oleh kelima tokoh lainnya. Linda memasuki gedung sekolah bersama dengan Ira, tetapi mereka terpisah di dalam gedung. Kesendirian dan teriakan 
teman-teman memanggil namanya memunculkan keberanian dalam diri Linda. Linda mulai memiliki motivasi untuk menemukan teman-temannya dan keluar dari gedung tersebut. Keberanian Linda tercermin dalam keputusannya untuk mengelilingi gedung sekolah yang gelap dan seram tersebut. Linda menyalakan senter ponselnya untuk mempermudah pencariannya. Penggambaran senter ponsel di dalam ruang yang gelap dapat menunjukkan sebuah kontras antara gelap dan terang. Kondisi gedung yang gelap dapat dimaknai sebagai sesuatu yang buruk, sedangkan senter ponsel Linda dapat dimaknai sebagai sesuatu yang baik. Senter ponsel yang dimiliki oleh Linda juga dapat dimaknai bahwa Linda membawa pertolongan atas permasalahan ini. Penggambaran gelap dan terang semakin diperkuat dalam gambar 8. Dalam gambar 8, Linda bertemu dengan babi ngepet. Linda tidak tahu cara melawan hantu tersebut, tetapi seiring perkembangan cerita, Linda mulai menyadari manfaat lain dari ponselnya. Ponselnya dapat digunakan untuk menerangi ruangan dan mengambil gambar. Pengambilan gambar selalu terjadi dengan kemunculan sinar kamera. Ketika Linda menghadapi babi ngepet dengan mengambil gambar, babi ngepet dapat dikalahkannya. Hal ini dapat menunjukkan bahwa kegelapan dapat dikalahkan dengan terang. Kondisi ini juga dapat dimaknai bahwa kejahatan tidak akan pernah menang melawan kebaikan.

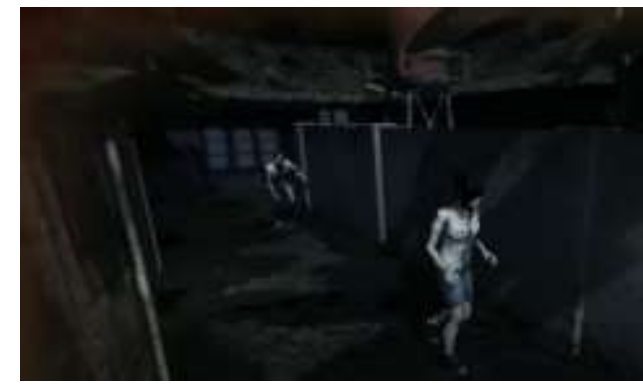

Gambar 9. Linda akan dibunuh oleh Yayan

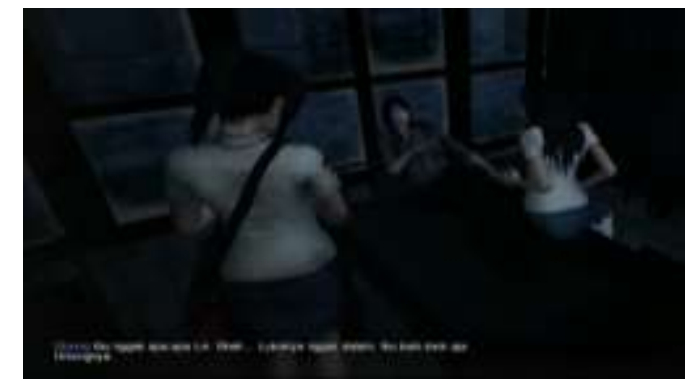

Gambar 10. Linda menolong Shelly dan Bu Siska

Dalam gambar 9, Yayan telah dirasuki oleh roh penunggu gedung tersebut. Yayan tidak memiliki kesadaran atas dirinya sendiri. Ketika Linda bertemu dengan Yayan, Yayan tidak mengenal Linda dan menganggapnya sebagai musuh yang harus dibunuh. Dalam gambar 10, Linda bertemu dengan Shelly dan Bu Siska yang sangat ketakutan atas keseraman gedung tersebut. Bu Siska meminta tolong kepada Linda untuk menemukan teman-temannya. Permintaan Bu Siska dapat menunjukkan kedewasaan dan kematangan Linda dalam memperbaiki permasalahan ini. Bu Siska sebagai orang dewasa digambarkan tidak memiliki kedewasaan dan keberanian sebaik Linda. Linda digambarkan memiliki keadaan yang paling baik dan berani untuk menemukan dan menyelamatkan kelima tokoh lainnya. Penggambaran ini dapat menunjukkan watak dan tindakan Linda yang berbeda dengan stereotip gender, seperti aktif, dapat diandalkan, dan tangguh. Yayan dan Doni sebagai tokoh laki-laki dalam game ini tidak memiliki gambaran watak dan tindakan setangguh Linda. Penggambaran watak seseorang yang tidak dapat dikaitkan dengan jenis kelamin tertentu. Kondisi ini senada dengan pemaparan Butler (1990) bahwa kebudayaan mengonstruksi tindakan dan watak seseorang berdasarkan dengan anatomis tubuhnya. Konstruksi gender mengatur perempuan dalam sisi feminin, tetapi perempuan juga dapat memiliki sisi maskulin. Dalam kedua gambar di atas, Linda tidak hanya digambarkan sebagai perempuan yang tangguh, namun Linda menjadi tokoh yang dibutuhkan oleh tokohtokoh lainnya, termasuk tokoh laki-laki. 


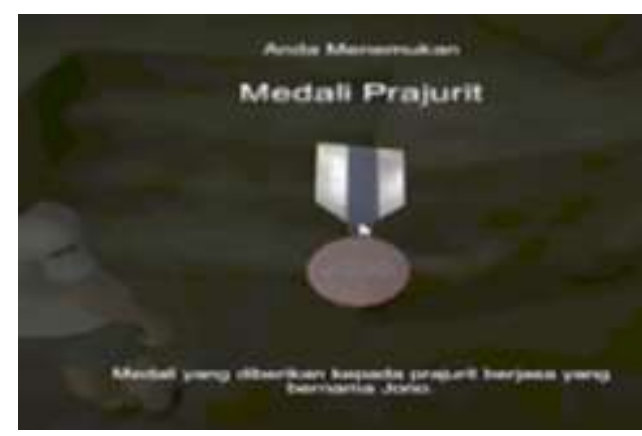

Gambar 11. Informasi yang diperoleh Linda

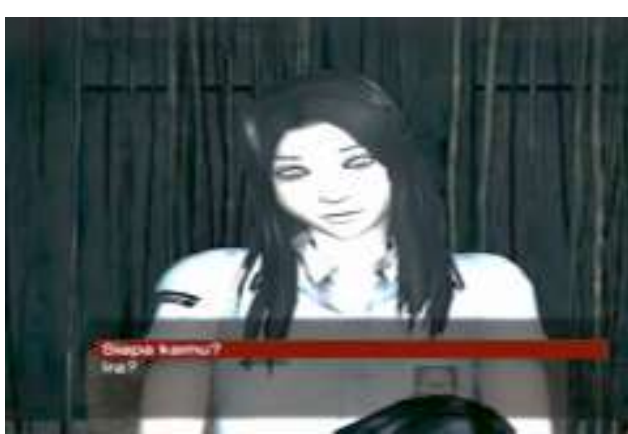

Gambar 12. Linda bertemu Ira

Penggambaran kontras antara terang dan gelap ditampilkan melalui kedua gambar di atas. Dalam gambar 11, Linda dapat memperoleh sebuah informasi dengan mendatangi sinar biru. Dalam gambar 12, Linda bertemu dengan Ira yang telah dirasuki oleh roh penunggu gedung sekolah. Pertemuan Linda dengan tokoh lain yang ditandai dengan sinar merah dapat menunjukkan keburukan peran tokoh tersebut. Ketika Linda bertemu babi ngepet pada gambar 8, Linda menemukan sinar merah di sekitar dirinya dan babi ngepet. Penggambaran sinar merah dapat dimaknai sebagai sesuatu yang tidak baik, sedangkan penggambaran sinar biru dapat dimaknai sebagai pertolongan. Selain itu, kedua gambar ini juga dapat menunjukkan manfaat pengelilingan Linda di gedung sekolah. Linda dapat mengumpulkan berbagai macam informasi untuk mempercepat keinginannya, yaitu menyelamatkan teman-temannya dan keluar dari gedung tersebut. Linda harus melihat informasi tersebut dari dekat atau mengambil gambar informasi tersebut. Dalam gambar 12, Linda memiliki kesempatan untuk memilih dua pilihan yang ditawarkan oleh roh yang merasuki Ira. Meskipun Linda diberikan dua pilihan, namun pilihan tersebut tidak memengaruhi pengembangan cerita. Jika Linda memilih pilihan yang sesuai dengan keinginan roh, maka roh tersebut akan memberikan informasi mengenai temanteman dan gedung sekolah.

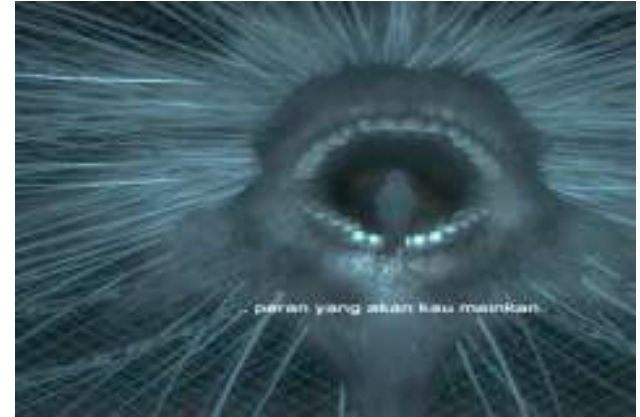

Gambar 13. Kemenangan Linda

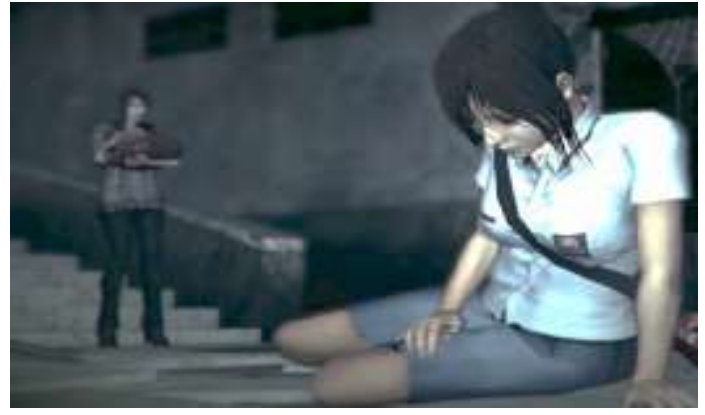

Gambar 14. Linda berhasil keluar dari Gedung

Permasalahan kontras antara gelap dengan terang kembali dihadirkan pada akhir game. Linda telah berhasil melawan hantu perempuan berpakaian merah. Kehadiran hantu perempuan ini dapat dimaknai sebagai pemimpin dari seluruh hantu-hantu gedung tersebut. Keberhasilan Linda dalam pertarungan ini membuat hantu perempuan tersebut memberikan sebuah kata-kata, yaitu "Jangan takuti peran yang akan kau mainkan." Perkataan hantu tersebut dapat dimaknai sebagai sebuah pesan untuk menguatkan Linda dalam menghadapi kehidupannya. Perkataan ini juga dapat dikaitkan dengan kegagalan Linda menolong teman-temannya untuk keluar dari gedung tersebut. Doni, Yayan, Ira, dan Shelly telah terjebak di dalam dunia lain yang berada dalam gedung tersebut. Keempat tokoh ini tidak dapat melepaskan diri dari dunia tersebut. Dalam gambar 14, keberhasilan Linda untuk keluar dari gedung tidak membawa kebahagiaan karena ia telah kehilangan keempat temannya. Gambar ini juga menunjukkan keberhasilan Bu Siska untuk 
keluar dari gedung tersebut, tetapi ia membawa bayi yang memiliki ekor ular. Kondisi ini dapat menunjukkan bahwa Bu Siska menggunakan keberanian Linda untuk memperoleh keinginannya, yaitu mendapatkan bayi tersebut.

\section{SIMPULAN}

Berdasarkan keseluruhan uraian di atas dapat disimpulkan bahwa pengadaptasian video game Dreadout berbeda dengan buku komiknya. Buku komik Dreadout menampilkan laki-laki sebagai tokoh utama. Bayu dan Sarip digambarkan sebagai tokoh yang kuat, berani, dan aktif. Bayu memiliki peranan yang sangat penting dalam menolong tokoh-tokoh lainnya, terutama tokohtokoh perempuan. Komik ini menggambarkan stereotip gender yang telah berlangsung dalam waktu yang lama dan dikonstruksi oleh masyarakat, seperti kepribadian perempuan yang lemah, kepribadian laki-laki yang kuat, dan peran laki-laki yang lebih penting daripada perempuan. Cerminan watak dan tindakan seorang tokoh berdasarkan jenis kelamin tidak ditampilkan kembali dalam video game Dreadout. Video game ini menampilkan gadis remaja sebagai tokoh utama. Linda digambarkan sebagai tokoh yang tangguh dan menolong tokoh-tokoh lainnya. Tindakan dan watak Linda dalam menolong dan menghadapi hantu-hantu dapat merepresentasikan simbol kekuatan perempuan.

Penggambaran Linda dapat mengubah dan mematahkan ideologi yang telah dibangun dalam media sebelumnya, yaitu buku komik. Keberanian Linda dalam menghadapi permasalahan yang dianggap cocok untuk tokoh laki-laki ditampilkan dalam sorotan kamera pembuka dan penutup video game. Video game selalu menggambarkan ketenangan Linda dalam menghadapi permasalahan ini. Pembuat video game atau Digital Happiness menggunakan citraan Linda sebagai sebuah pandangan baru mengenai perempuan. Linda tidak merepresentasikan perempuan yang sesuai dengan stereotip gender. Perempuan tidak digambarkan sebagai makhluk nomor dua dan tidak penting dalam sebuah game genre horor kesintasan. Perempuan digambarkan memiliki watak dan tindakan yang sama dengan tokoh utama laki-laki dalam game genre horor. Hal ini dapat menunjukkan bahwa Digital Happiness ingin memberikan motivasi kepada perempuan untuk menjadi lebih mandiri, kuat, tangguh. Digital Happiness juga ingin mensosialisasikan sisi maskulinitas kepada pemain game-nya, terutama pemain laki-laki untuk tidak mengukuhkan stereotip gender.

\section{DAFTAR PUSTAKA}

Adi, C. S. 2015. "Komunikasi Pemasaran Video Game Melalui Media Digital: Studi Kasus Pemanfaatan Internet Dalam Komunikasi Pemasaran Video Game Dreadout oleh PT Digital Semantika Indonesia.” Skripsi. Yogyakarta: Universitas Gadjah Mada.

Butler, Judith. 1990. Gender Trouble. New York: Routledge.

Chodorow, Nancy. 1983. "Family Structure and Feminine Personality." Dalam Women, Culture, and Society, disunting oleh M. Z. Rosaldo \& L. Lamphere. Stanford: Stanford University Press.

Fakih, Mansour. 2013. Analisa Gender dan Transformasi Sosial. Yogyakarta: Pustaka Pelajar.

Fehrle, Johannes. 2015. "Gaming into the Heart of Darkness: Adapting Conrad/Coppola." South Atlantic Review, 80:3-4. 
Greimas, A. J. 1987. On Meaning: Selected Writings in Semiotic Theory (Theory and History of Literature). University of Minnesota

Happiness, Digital. 2013. Dreadout. Bandung: Mizan Media Utama.

- 2020. "Digital Happiness." http://www.digitalhappiness.net/.

- 2014. Game Dreadout. Bandung: Digital Happiness.

Hutcheon, Linda. 2006. A Theory of Adaptation. New York: Routledge.

Kaklamanidou, Betty \& Maria Katsaridou. 2013 “"Silent Hill”: Adapting a Video Game.” Literature/Film Quarterly, 41 (4):266-277.

Leondra, Yusuf. 2018. "Tinjauan Visualisasi Karakter Linda Melinda dalam Permainan Dreadout Menggunakan Analisa Deskriptif.” Skripsi. Bandung: Universitas Komputer Indonesia.

Mahardika, Wira. 2018. "Visual Illustration Analysis on Dreadout Game Poster Through Semiotics." Proceedings of the International Conference on Business, Economic, Social Science and Humanities (ICOBEST 2018). DOI: 10.2991/icobest-18.2018.91.

Perron, Bernard. 2009. Horror Video Game: Essays on the Fusion of Fear and Play. Jefferson: McFarland \& Co.

Sunden, Jenny \& Malin Sveningsson. 2012. Gender and Sexuality in Online Game Cultures: Passionate Play. New York: Routledge. 